\title{
Environmental Radiation Measurement and Assessment of Natural Radioactivity in Soil, Water and Vegetation
}

\author{
Nandi-Esom Chariette Ereh, Meng Zhang* \\ Nuclear Science and Technology, Harbin Engineering University, Harbin, China \\ Email: *achachaereh2001@yahoo.com
}

How to cite this paper: Ereh, N.-E.C. and Zhang, M. (2018) Environmental Radiation Measurement and Assessment of Natural Radioactivity in Soil, Water and Vegetation. Journal of Applied Mathematics and Physics, 6, 2330-2337.

https://doi.org/10.4236/jamp.2018.611194

Received: October 29, 2018

Accepted: November 19, 2018

Published: November 22, 2018

\begin{abstract}
Environmental radioactivity is produced by radioactive materials in the human environment. While some radioisotopes, such as strontium-90 $\left({ }^{90} \mathrm{Sr}\right)$ and technetium-99 $\left({ }^{99} \mathrm{Tc}\right)$, are only found on Earth as a result of human activity, and some, like potassium $-40\left({ }^{40} \mathrm{~K}\right)$, are only present due to natural processes, a few isotopes, e.g. tritium $\left({ }^{3} \mathrm{H}\right)$, result from both natural processes and human activities. The concentration and location of some natural isotopes, particularly uranium-238 $\left({ }^{238} \mathrm{U}\right)$, can be affected by human activity because of the constant exposure of Human beings to radiation caused by terrestrial, extra-terrestrial and anthropogenic radio nuclides, it is necessary to determine and estimate the activity of various radio nuclides in environmental media such as vegetation, soil, and water. In the present research, the activities of ${ }^{226} \mathrm{Ra},{ }^{232} \mathrm{Th}$ and ${ }^{40} \mathrm{~K}$ are measured in soil, vegetation and water samples, collected from Yangdong District, Yangxi County, and Yangjiang County of Guangdong Province, China using an HPGe based gamma spectrometry system. The measured mean activity of ${ }^{226} \mathrm{Ra},{ }^{232} \mathrm{Th}$ and ${ }^{40} \mathrm{~K}$ in soil samples was found to be $31.19 \pm 1.2,47.00 \pm 2.30$ and $589.31 \pm 17.52 \mathrm{Bqkg}^{-1}$, respectively. The measured mean activity of these radionuclides in all water samples was found to be below minimum detectable activity. The measured mean activity of ${ }^{226} \mathrm{Ra},{ }^{232} \mathrm{Th}$ and ${ }^{40} \mathrm{~K}$ in vegetation samples was $19.92 \pm 3.09,25.36 \pm 8.11$ and $4982.94 \pm 85.68 \mathrm{Bqkg}^{-1}$, respectively. No anthropogenic ${ }^{137} \mathrm{Cs}$ was detected in these environmental samples. Mean radium equivalent activity (Raeq), external radiation hazard index (Hex), internal radiation hazard index (Hin) and absorbed dose rate (D) for the area under study were determined as $142.92 \mathrm{Bqkg}^{-1}, 0.38,0.47$ and $66.47 \mathrm{nGyh}^{-1}$, respectively. The annual effective dose equivalent (AEDE) varied in the range from 0.03 to 0.12 $\mathrm{mSvy}^{-1}$. It is concluded that the surveyed area do not pose any significant radiological risk to the population and environment.
\end{abstract}




\section{Keywords}

High Purity Germanium Detector, Radium, Thorium, Potassium, Radium Equivalent Activity, Radiation Hazard Indices and Environment Measurement

\section{Introduction}

Radiation of natural origin at the earth's surface consists of two components, namely cosmic rays and radiation of the radioactive nuclides in the earth's crust, the latter component, the terrestrial radiation, originates mainly from the so-called primordial radioactive nuclides originated in the early stage of the formation of the solar system. Uranium, thorium and potassium are the main elements contributing to natural terrestrial radioactivity. Uranium has two primary isotopes ${ }^{238} \mathrm{U}(\mathrm{T}=4.47 \times 109 \mathrm{y})$ and ${ }^{235} \mathrm{U}(\mathrm{T}=7.07 \times 108 \mathrm{y})$ which, at present, occur in the proportion of $99.3 \%{ }^{238} \mathrm{U}$ and $0.7 \%{ }^{235} \mathrm{U}$. Both exhibit long and complex decay series. Thorium $\left(\mathrm{T}=1.41 \times 10^{10} \mathrm{y}\right)$ has only one isotope, while potassium has three isotopes $\left({ }^{39} \mathrm{~K},{ }^{40} \mathrm{~K},{ }^{41} \mathrm{~K}\right)$, with ${ }^{40} \mathrm{~K}(\mathrm{~T}=1.28 \times 1010 \mathrm{y})$ being the only radioactive isotope of natural abundance of $(0.012 \%$ of potassium). Knowledge about the radiation of natural origin is very important being the largest source of population dose and its assessment is important as a baseline with which radiation protection standards may be formulated. Additionally, natural radiation involves the entire global population [1] (EPA, 2007). The exposure of men to these naturally occurring radio nuclides is, and has been, an unavoidable consequence of their presence in the earth's crust, surface, soil, air, food and water. It is now widely accepted among experts that natural radiation accounts for the greatest part of public radiation exposure [2] (UNSCEAR, 2000). Moreover, the common understanding of the exposure of man to the natural radiation environment in the 1960s was fairly simple compared with the current understanding, due to the increased public concern and awareness about radioactive pollution, the aim of the present research work was to determine the radioactivity levels in a variety of environmental samples of Guangdong Province, China. The main objective of this study is to estimate the type and amount of natural and fallout radioactivity levels in the soil, vegetation, water and other environmental samples and to establish base line data. A radiological environmental monitoring survey has already been accomplished for some other specific areas of Guangdong Province. The results are published.

\section{Material and Methods}

Ten samples were collected from various locations of Yangdong district, Yangxi County, and Yangjiang district (Figure 1). The area under study is located between the longitudes of $32^{\circ} 34^{\prime} \mathrm{N}$ and $33^{\circ} 72^{\prime} \mathrm{N}$ and latitudes of $71^{\circ} 48^{\prime} \mathrm{E}$ and $72^{\circ} 32^{\prime} \mathrm{E}$. The sampling was carried out following the systematic grid of $25 \times 25$ square kilometers. The total area covered is approximately 1198 square miles. 


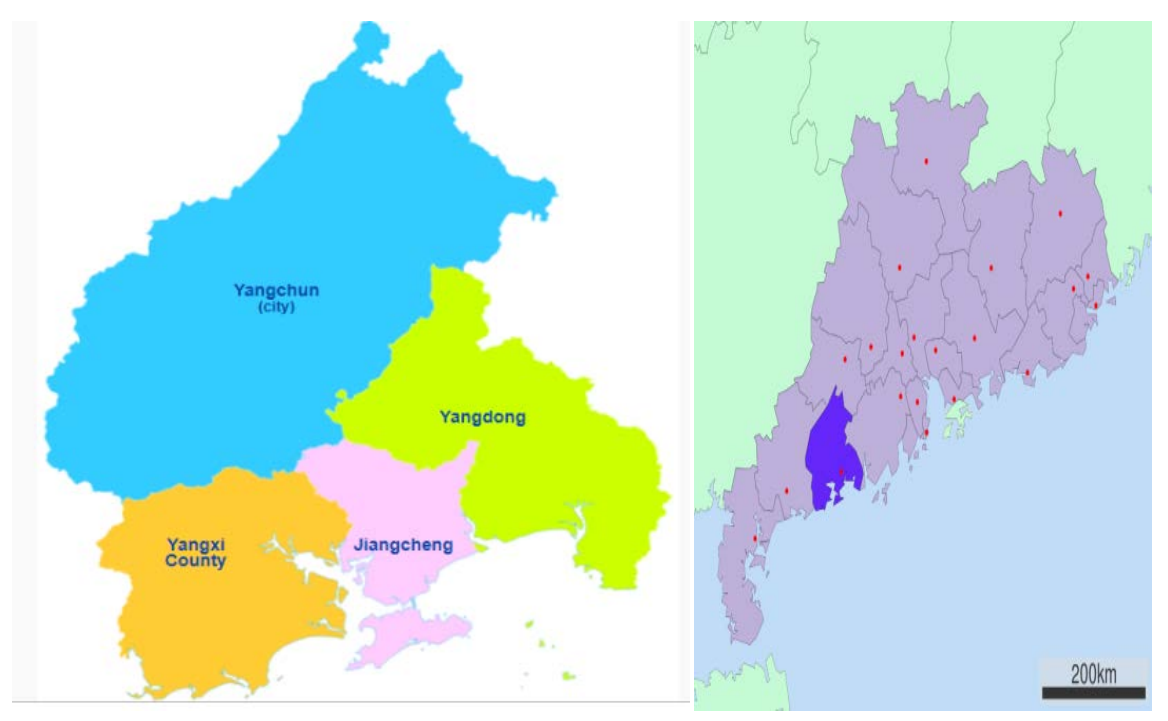

Figure 1. Coordinates of sampling sites.

Three type of environmental media were collected from the area under study i.e. soil, water and vegetation. The sampling sites were chosen to be relatively flat, open and undisturbed. The soil samples were taken from the upper $5 \mathrm{~cm}$ layer with a coring tool. Vegetation was collected from different places in the selected site and was combined to make a single representative. In order to prevent contamination with soil, the vegetation sample was cut to a height of $5 \mathrm{~cm}$ from the ground. The soil and vegetation samples were collected in polyethylene bags and labeled properly (date and place). Water samples were collected in 2-liter cans. After collection, the samples were stored to avoid degradation, spoiling or other decomposition.

In the laboratory, after removing the roots and stones, soil samples were oven dried at $150^{\circ} \mathrm{C}$ until the sample weight became constant and then they were ground and sieved. About $200 \mathrm{~g}$ of soil samples were stored in air tight cylindrical plastic containers for at least 4 weeks before counting, so that secular equilibrium can be attained between the progeny and the ${ }^{226} \mathrm{Ra}$. In order to remove all organic matter, the vegetation samples were ashed in a muffle furnace at a temperature of $350^{\circ} \mathrm{C}$. For ashing operation, as recommended, stainless steel trays were used. In the case of water samples, evaporation was carried out on a hot plate for volume reduction from 2 liter to $125 \mathrm{ml}$. In order to maintain the homogeneity of the water samples and to avoid adsorption of radio nuclides on the walls of the container, all the samples were acidified with $0.1 \mathrm{~N} \mathrm{HNO}_{3}$. The temperature for evaporation was kept below the boiling point of water. Samples were transferred and stored in air tight containers [3] (AERB, 2003) for over 20 days to allow for $\mathrm{Ra}-\mathrm{Rn}$ equilibrium [4] (Veiga et al., 2006) before radiometric analysis. To estimate the activity levels of ${ }^{40} \mathrm{~K},{ }^{226} \mathrm{Ra},{ }^{232} \mathrm{Th}$ and ${ }^{137} \mathrm{Cs}$ a high resolution gamma-ray spectrometer consisting of a HPGe detector coupled to PC based MCA card was used. The relative efficiency of the detector was $30 \%$ and the resolution $2.23 \mathrm{keV}$ at 1332 gamma-rays of ${ }^{60} \mathrm{Co}$. The detector was equipped 
with 8192-channels and was shielded in an $8 \mathrm{~cm}$ lead chamber with an inner lining of $0.5 \mathrm{~cm}$ thick copper plate to reduce the background. The results were analyzed by using Geni-2000 software. Efficiency calibration of the detection system was done with Soil-327, obtained from IAEA. Every sample was counted for 65,000 seconds. A background sample was normally analyzed at the start of each month and background counts were then subtracted from the total counts to obtain sample counts during that period. ${ }^{40} \mathrm{~K}$ and ${ }^{137} \mathrm{Cs}$ were analyzed by their single peaks of 1460 and $661 \mathrm{keV}$, respectively. However, the analysis of ${ }^{226} \mathrm{Ra}$ and ${ }^{232} \mathrm{Th}$ was based upon the peaks of progeny in equilibrium with their parent radio nuclides.

\section{Results and Discussion}

The activity of ${ }^{226} \mathrm{Ra},{ }^{232} \mathrm{Th}$ and ${ }^{40} \mathrm{~K}$ in the soil, water and vegetation samples have been measured and the corresponding results are shown in Table 1. The large variations in the activity of these radio nuclides are due to non-uniform distribution of the different primordial radionuclide in the soil of the study area. The activity of ${ }^{226} \mathrm{Ra},{ }^{232} \mathrm{Th},{ }^{40} \mathrm{~K}$ and ${ }^{137} \mathrm{Cs}$ in the water samples of different areas has been measured and it was found that that measured activity of ${ }^{226} \mathrm{Ra},{ }^{232} \mathrm{Th},{ }^{40} \mathrm{~K}$ and ${ }^{137} \mathrm{Cs}$ in all the samples of water taken from different areas of Districts are

Table 1 . Specific activity measured in soil, water and vegetation samples.

\begin{tabular}{|c|c|c|c|}
\hline \multirow{2}{*}{$\begin{array}{c}\text { Media } \\
\text { Samples Site.No }\end{array}$} & \multicolumn{3}{|c|}{ Specific Activity $\left(\mathrm{Bq} \mathrm{kg}^{-4}\right)$} \\
\hline & ${ }^{236} \mathrm{Ra}$ & ${ }^{232} \mathrm{Th}$ & ${ }^{40} \mathrm{~K}$ \\
\hline 1. Soil & $35.850 \pm 1.31$ & $45.199 \pm 2.45$ & $529.84 \pm 20.15$ \\
\hline Water & Minimum detectable activity & MDA & MDA \\
\hline vegetation & $25.49 \pm 3.71$ & $28.24 \pm 0.21$ & $5933.07 \pm 78.76$ \\
\hline 2. soil & $27.588 \pm 1.14$ & $39.352 \pm 2.16$ & $554.93 \pm 76$ \\
\hline vegetation & $18.35 \pm 1.16$ & $17.36 \pm 0.24$ & $8115.21 \pm 52.85$ \\
\hline 3. soil & $28.022 \pm 1.26$ & $51.680 \pm 2.48$ & $610.11 \pm 20.33$ \\
\hline vegetation & $15.15 \pm 5.08$ & $38.02 \pm 0.22$ & $3186.05 \pm 94.70$ \\
\hline 4. soil & $33.741 \pm 1.13$ & $43.847 \pm 2.11$ & $586.72 \pm 17.45$ \\
\hline vegetation & $29.90 \pm 3.74$ & $28.80 \pm 3.74$ & $27.75 \pm 65$ \\
\hline 5. soil & $42.092 \pm 1.29$ & $65.301 \pm 2.49$ & $635.80 \pm 19.60$ \\
\hline vegetation & $12.74 \pm 3.63$ & $22.36 \pm 0.22$ & $4530.13 \pm 74.62$ \\
\hline $\begin{array}{c}\text { 6. soil } \\
\text { vegetation }\end{array}$ & $\begin{array}{c}20.022 \pm 1.13 \\
4267.03 \pm 81.98\end{array}$ & $33.711 \pm 2.20$ & $566.11 \pm 18.86$ \\
\hline 7. soil & $30.957 \pm 1.18$ & $57.039 \pm 2.33$ & $602.97 \pm 15.59$ \\
\hline vegetation & $10.48 \pm 2.68$ & $24.30 \pm 0.15$ & $2106.05 \pm 51.15$ \\
\hline 8. soil & $27.619 \pm 1.22$ & $33.671 \pm 2.28$ & $522.01 \pm 19.39$ \\
\hline vegetation & $2952.01 \pm 54.46$ & $2951.01 \pm 58.45$ & $2950.01 \pm 58.45$ \\
\hline 9. soil & $31.13 \pm 1.20$ & $58.46 \pm 2.37$ & $371.77 \pm 18.18$ \\
\hline vegetation & $47.97 \pm 7.70$ & $25.76 \pm 3.97$ & $6947.13 \pm 86.15$ \\
\hline 10. Soil & $37.329 \pm 1.15$ & $53.827 \pm 2.18$ & $589.30 \pm 17.525$ \\
\hline vegetation & $15.77 \pm 9.25$ & $15.77 \pm 9.27$ & $953.12 \pm 99.70$ \\
\hline
\end{tabular}


equal to the minimum detectable activity of the detector. Table 1 represents the measured activity of ${ }^{226} \mathrm{Ra},{ }^{232} \mathrm{Th}$ and ${ }^{40} \mathrm{~K}$ in all the sample of soil and vegetation taken from different areas. The maximum and minimum activity of ${ }^{226} \mathrm{Ra}$ has been found $42.09 \pm 1.29 \mathrm{Bqkg}^{-1}$ in Yangxi and $20.02 \pm 1.13 \mathrm{Bqkg}^{-1}$ in Yangjiang respectively. The mean radioactivity of ${ }^{226} \mathrm{Ra}$ in the study area was $31.47 \pm 1.20$ $\mathrm{Bqkg}^{-1}$, which is less than the world average value, i.e. $50 \mathrm{Bqkg}^{-1}$ [2] (UNSCEAR 2000, ed. U. N. 2000).

Measured activity of ${ }^{232} \mathrm{Th}$ in all the samples of soil taken from study area are also shown in Table 1 . The maximum and minimum activity of ${ }^{232} \mathrm{Th}$ has been found $65.30 \pm 2.49 \mathrm{Bqkg}^{-1}$ in Yangjiang and $33.67 \pm 2.28 \mathrm{Bqkg}^{-1}$ in Yangxi County, and, respectively. The mean radioactivity of ${ }^{232} \mathrm{Th}$ in the study area is $47.00 \pm 2.30 \mathrm{Bqkg}^{-1}$, which is less than the world average value, i.e. $50 \mathrm{Bqkg}^{-1}$ [2] (UNSCEAR 2000, ed. U. N. 2000). Table 1 also represents the measured activity of ${ }^{40} \mathrm{~K}$ in all the soil sample of the study area. According to the data, the maximum and minimum activity of ${ }^{40} \mathrm{~K}$ has been found $635.80 \pm 19.60 \mathrm{Bqkg}^{-1}$ in Yangdong and $371.77 \pm 18.18 \mathrm{Bqkg}^{-1}$ in Yangxi County, respectively. The mean radioactivity of ${ }^{40} \mathrm{~K}$ in the study area is $589.31 \pm 17.52 \mathrm{Bqkg}^{-1}$ and it is higher than the mean value of the world i.e., $500 \mathrm{Bqkg}^{-1}$, the world mean specific concentration of 40Kvaries from 100 to 700 Bqkg-1 [5] (Mcaulay; Moran, 1988) because its occurred abundant in the earth crust. Table 2 represents the measured activity of ${ }^{137} \mathrm{Cs}$ in all the soil, water and vegetation samples of the study area, less than the minimum detection limit of the detector. In present study, it has been observed that the specific activity of natural radionuclides in the soil is not uniform but varies from soil to soil depending upon the geological character and different minerals present in the soil. Similarly, the activity of ${ }^{226} \mathrm{Ra},{ }^{232} \mathrm{Th}$ and ${ }^{40} \mathrm{~K}$

Table 2. Radiation doses measured in soil samples.

\begin{tabular}{|c|c|c|c|c|c|}
\hline \multirow[b]{2}{*}{ Soil-1 } & \multicolumn{2}{|c|}{ Dose rate } & \multicolumn{2}{|c|}{ Raeq Activity } & \multirow{2}{*}{$\frac{\text { AEDE }}{(\mathrm{mSvy}-1)}$} \\
\hline & $\left(\mathrm{nGyh}^{-1}\right)$ & $\left(\mathrm{Bq} \mathrm{kg}^{-1}\right)$ & $\mathrm{H}_{\mathrm{ex}}$ & $\mathrm{H}_{\mathrm{in}}$ & \\
\hline Soil-2 & 65.71 & 141.28 & 0.38 & 0.48 & 0.12 \\
\hline Soil-3 & 59.29 & & 126.59 & 0.42 & 0.11 \\
\hline Soil-4 & 68.96 & 148.04 & 0.40 & 0.48 & 0.13 \\
\hline Soil-5 & 66.17 & 141.62 & 0.38 & 0.47 & 0.12 \\
\hline Soil-6 & 85.28 & 184.43 & 0.50 & 0.61 & 0.16 \\
\hline Soil-7 & 52.28 & 111.82 & 0.30 & 0.36 & 0.10 \\
\hline Soil-8 & 73.72 & 158.95 & 0.43 & 0.51 & 0.14 \\
\hline Soil-9 & 54.46 & 115.98 & 0.31 & 0.14 & 0.39 \\
\hline Soil-10 & 64.29 & 140.87 & 0.38 & 0.46 & 0.12 \\
\hline $\operatorname{Max}$ & 85.28 & 184.43 & 0.50 & 0.61 & 0.16 \\
\hline Min & 52.76 & 111.82 & 0.30 & 0.36 & 0.10 \\
\hline Mean & 66.47 & 142.92 & 0.38 & 0.47 & 0.12 \\
\hline
\end{tabular}


in the vegetation sample of different sites of Yangijian has been also represented in the Table 2. The maximum and minimum activity of ${ }^{226} \mathrm{Ra}$ has been found $29.90 \pm 3.74 \mathrm{Bqkg}^{-1}$ in Jiangchen $10.48 \pm 2.68 \mathrm{Bqkg}^{-1}$ in Yangdong respectively. The mean radioactivity of ${ }^{226} \mathrm{Ra}$ in the study area is $19.92 \pm 3.09 \mathrm{Bqkg}^{-1}$. In all the samples of vegetation taken from study area the maximum and minimum activity of ${ }^{232} \mathrm{Th}$ has been found to be $51.77 \pm 0.20 \mathrm{Bqkg}^{-1}$ and $17.36 \pm 0.24 \mathrm{Bqkg}^{-1}$ in Yangijian and Yangxi county respectively. The mean radioactivity of ${ }^{232} \mathrm{Th}$ in the study area is $25.36 \pm 8.11 \mathrm{Bqkg}^{-1}$. Similarly, the maximum and minimum activity of ${ }^{40} \mathrm{~K}$ has been found to be $8115.21 \pm 152.85 \mathrm{Bqkg}^{-1}$ in Yangxi and $2106.05 \pm$ $51.15 \mathrm{Bqkg}^{-1}$ in Jiangcheng respectively. The mean radioactivity of ${ }^{40} \mathrm{~K}$ in the study area is $4982.94 \pm 85.68 \mathrm{Bqkg}^{-1}$.

\section{Measurements of Radioactivity Parameters}

\subsection{Gamma Dose Rate}

The variation in dose rates (D) which was determined by the formula given below for soil samples was found in the range of $85.28 \mathrm{nGyh}^{-1}$ to $52.76 \mathrm{nGyh}^{-1}$. The highest absorbed dose was found in sample of yangxi while the lowest absorbed dose was found in sample of yangdong. The mean absorbed dose rate of the study area is $66.47 \mathrm{nGyh}^{-1}$, which is $5.31 \%$ lower than world mean value i.e. 70 $\mathrm{nGyh}^{-1}$, equation of the Gamma dose rate (D) of the study area.

$$
D\left(n G y h^{-1}\right)=0.46 C_{R a}+0.62 C_{T h}+0.04 C_{k}
$$

where $D$ is the absorb dose rate, $C_{R a}, C_{T h}$ and $C_{K}$ are the activity of ${ }^{226} \mathrm{Ra},{ }^{232} \mathrm{Th}$ and ${ }^{40} \mathrm{~K}[6]$ (Berekta and Mathew, 1985).

\subsection{Radium Equivalent Activity}

The radioactivity has been defined in terms of radium equivalent activity (Raeq) in $\mathrm{Bqkg}^{-1}$ to compare the specific activity of materials containing different amounts of ${ }^{226} \mathrm{Ra},{ }^{232} \mathrm{Th}$ and ${ }^{40} \mathrm{~K}$ by using the given equation. Radium equivalent activity (Raeq) calculated for different soil samples investigated in the present study are given in Table 2. Radium equivalent activity (Raeq) is varying in the ranges $184.43 \mathrm{~Bq} \mathrm{~kg}-1$ in Zhaoging to $111.82 \mathrm{Bqkg}^{-1}$ in Yangijian.

$$
R_{\text {aeq }}=C_{R a}+1.43 C_{T h}+0.077 C_{K}
$$

where $C_{R a}, C_{T h}$ and $C_{K}$ are the specific activities of ${ }^{226} \mathrm{Ra},{ }^{232} \mathrm{Th}$ and ${ }^{40} \mathrm{~K}\left(\mathrm{Bqkg}^{-1}\right)$ respectively, The mean of radium equivalent activity in the current area is 142.92 $\mathrm{Bqkg}^{-1}$, less than the $370 \mathrm{Bqkg}^{-1}$ which is the safe limit as recommended by the Organization for Economic Cooperation and Development.

\subsection{External Hazards Index}

The calculated external hazard $\left(H_{e x}\right)$ values are varies from 0.50 to 0.30 , calculated from given equation, the lowest value is 0.30 in Yangxi and the highest value is 0.50 in Yangdong [6] The external hazard index (Hex) was calculated from the equation according to reference (Berekta and Mathew, 1985). 


$$
H_{e x}=\frac{A_{R a}}{370}+\frac{A_{T h}}{259}+\frac{A_{K}}{4810}
$$

The mean value for sampling area is 0.38 . The current mean external hazard index is $0.38,31.57 \%$ less than world mean value i.e. 0.5 . Equation (3) shows the external hazards of the sampling area.

\subsection{Internal Hazards Index}

The calculated internal hazard $\left(H_{\text {in }}\right)$ values varies between 0.20 to 0.35 , calculated from equation, the lowest value found in soil sample of Zhaoging the highest value represent in soil sample of Jiangcheng. The mean internal hazards index for the area is 0.27 , which is less then to the world mean value i.e. 0.5. Therefore, based on $H_{i n}$ and $H_{e x}$ results; we can say there is no health hazard from the soil of selected areas, and is expressed mathematically by [6] (Berekta \& Mathew, 1985).

$$
H_{i n}=\frac{A_{R a}}{185}+\frac{A_{T h}}{259}+\frac{A_{K}}{4810}
$$

\subsection{Annual Effective Dose Equivalent}

Annual effective dose equivalents (AEDE) were calculated from the formula given below, the variation in Annual effective dose equivalent was found to be $0.10 \mathrm{mSvy}^{-1}$ to $0.16 \mathrm{mSvy}^{-1}$, which represents the lowest value in soil samples of Jiangcheng and the highest value in soil sample of Yangdong. The mean annual effective dose for the study area is 0.12 , which is negligible compare to world mean value of $0.3 \mathrm{mSvy}^{-1}$ [2] (UNSCEAR 2000, ed. U. N. 2000).

$$
A E D E(m s v / y)=D(n G y / y) \times 8760(h / h) \times 0.3 \times 0.7(s v / G y) \times 10^{-6}
$$

\section{Conclusion}

Over all, the concentration of all the radio nuclides are less than the safe limit, they do not pose any health problem to the inhabitants of the study area. However, the data may provide a general background level for the area studied and may also serve as a guideline for future measurement and assessment of radio nuclides in case of any radiological emergency. All results of the present work indicate that the area under investigation has a normal level of natural background. In a global and long term perspective, the protection of the public and the environment is important for the well-being of present and future generations and for equitable and sustainable development. Measuring the level of radioactivity during the routine discharges of radionuclides in the environment is a prerequisite for the assessment and evaluation of radiological impacts. Models are used in combination with measurements to assess exposure to people, when areas have been contaminated. In present study, it has been observed that the specific activity of natural radionuclides in the soil is not uniform but varies from soil to soil depending upon the geological character and different minerals present in the soil. 


\section{Acknowledgements}

The authors acknowledge financial support by the [Fundamental Research Funds for the Central Universities] under Grant (GK2150260120); [National Natural Science Foundation of China under Grant] (Nos. 51104050); [Natural Science Foundation of Heilongiang Province] under Grant (No. E201709); [Technology Foundation for Selected Overseas Chinese Scholar of Heilongjiang Province] under Grant (No. 159150130002); and [Postdoctoral Scientific Research Developmental Fund of Heilongjiang Province] under Grant

(LBH-3236310448) for supporting this work.

\section{Conflicts of Interest}

The authors declare no conflicts of interest regarding the publication of this paper.

\section{References}

[1] Environmental Protection Agency (EPA) (2007) United States. Ionizing Radiation Fact Book. EPA. Office of Radiation and Indoor Air. EPA-402-F-06e061.

[2] United Nation Scientific Committee on the Effects of Atomic (UNSCEAR) (2000) Radiation Sources and Effects of Ionizing Radiation. United Nations. Report of the United Nations Scientific Committee on the Effect of Atomic Radiation to General Assembly, New York.

[3] Atomic Energy Regulatory Board (AERB) (2003) Accreditation of Laboratories for Measurement of Radionuclide Content in Commodities. Atomic Energy Regulatory Board, Mumbai.

[4] Veiga, R., Sanches, N., Anjos, R.M., Macario, K., Bastos, J., Iguateny, M., et al. (2006) Measurement of Natural Radioactivity in Brazilian Beach Sands. Radiation Measurements, 41, 189e196. https://doi.org/10.1016/j.radmeas.2005.05.001

[5] Mcaulay, I.R. and Moran, D. (1988) Natural Radioactivity in Soil in the Republic of Ireland. Radiation Protection Dosimetry, 24, 47-49. https://doi.org/10.1093/oxfordjournals.rpd.a080239

[6] Berekta, J. and Mathew, P.J. (1985) Natural Radioactivity in Australian Building Materials, Industrial Waste and Byproduct. Health Physics, 48, 87e95. 